\title{
Influence the Composition of the Core Mixture to the Occurrence of Veining on Castings of Cores Produced by Cold-Box-Amine Technology
}

Martina Hrubovčáková, Iveta Vasková, Martin Conev, Marianna Bartošová, Peter Futáš

Institute of Metallurgy, Faculty of Metallurgy, Technical University in Košice, Slovakia, E-mail: martina.hrubovcakova@tuke.sk, iveta.vaskova@tuke.sk,martin.conev@tuke.sk,marianna.bartosova@tuke.sk,peter.futas@tuke.sk

\begin{abstract}
Method of cold-box-amine is widespread and frequently used technology for the production of cores. [1] Characteristic defect castings of ferrous alloys, which often accompanies the use of amine - Cold box cores are veining . Survey, it was found that $77 \%$ of those surveyed foundries have problems with veining, $71 \%$ foundries solves this problem ( or try to tackle ) anti veining ingredients in nuclear and molding compounds, but only $29 \%$ considered their " antiveining " method for successful and favourable. [2] Article discusses the possibilities of elimination veining. Ingredients called additives lower the temperature at which the $\mathrm{SiO}_{2}$ begin to soften and form a melt at the surface of the grains, reduce the reactivity and increase the temperature of transition to a tridimit and cristobalit. These passages encourage increased tensions subsurface sand and reduce stress for the formation of veining on the surface of the core or mold. Experiments were performed to assess the impact of silica sands and the impact of additives on the quality of the casting surface.
\end{abstract}

Keywords: core mixture, veining, cold-box-amine

\section{References}

[1] BRACE R., STUART W., BURIAN A., NOVOTNÝ J. (1999). Production of molds and cores to self-hardening mixture with a binder system alphaset. Slévárenství, 1999. ISSN 0037-6825

[2] NĚMEC, M., BEDNÁ̌̌, B., STUNOVÁ, B. (2009). Teorie slévání, ČVUT, Praha

[3] JELÍNEK P. (1996). Casting sand - sand mixtures connective system. ISBN 80-7078-326-5, VŠB - TU Ostrava 1996

[4] KARSAY, S.I. (1976). Ductile Iron vol. 1 - Production. QIT - Fer et Titane Inc, Montreal

[5] HRUBOVČÁKOVÁ M, VASKOVÁ I. (2015). Possibilities of burrs elimination from cores produced with coldbox-amine technology, Acta metallurgica slovaca. Roč. 21, č. 1 (2015), s. 78-85. - ISSN 1335-1532

[6] GEDEONOVÁ, Z. (1990). Teória zlievárenských pochodov, Alfa, Košice

[7] VASKOVÁ I., ŠEBEK P., BARTO M. (2006). Practical experience with core production technology of cold box. Acta mechanica slovaca, 2b / 2006, ročník 10, Košice, ISSN 1335 - 2393, str. 449 - 454

[8] FLORES C., RAMOS E., RAMÍREZ M., GONZÁLES C. (2010). Applied pressure control risering of a ductile iron sand casting, In: Procceedings of METAL 2010, Tanger, s.r.o., Ostrava

[9] VASKOVÁ I., SMOLKOVÁ M., MALIK J., EPERJEŠI Š. (2008). Experience in forming and core mixtures by Alphaset technology, archives of foundry engineering published quarterly as the organ of the foundry commission of the polish academy of sciences ISSN (1897-3310) volume 8 issue 2/2008 $141-14431 / 2$

[10] LATTNER, M., HOLESOVSKY, F. (2014). Effect of Machining the Load Capacity Notched Components. In: Manufacturing Technology, vol. 14, 2014, pp. 47-50

[11] FOŠUM, J., ŠEBESTA, B. (2003). Recent and perspective methods testing of sand mixtures in foundries. Vol. 42, 2003, no.10, p.410 - 415, (in Czech). slévarenství, ISSN 0037-6825

[12] JELÍNEK P., MIKŠOVSKÝ F. (2004). The mechanism of the products. International Conference: casting defects caused by mold materials. p. 17, ISBN 80-02-01632-7, Mílovy 2004

[13] DZIAKOVÁ M., VASKOVÁ I., FECKO D. (2010). Influence of Operating factors on properties of furan mixtures, Acta Metallurgica slovaca, vol. 16, 2010, no. 1, p. 58-63, ISSN:1335-1532

[14] DAHLMANN M. ET AL. (2002). Synthetic foundry grog brings new opportunities, Slévarenství 2002, č.5-6, s.181-184 ISSN 0037-6825

[15] WEICKER, G., VONDRÁČEK, R. (1999). Special binder systems cold box and alternatives for the production of cores in foundries light metal alloys, Slévárenství 1999,č.5,s.265-269 ISSN 0037-6825 
[16] CONEV M., VASKOVÁ I., HRUBOVČÁKOVÁ M., HAJDÚCH P. (2016). Impact of Silica Sand Granulometry on Bending Strength of Cores Produced by ASK Inotec Process. In: Manufacturing Technology, vol. 16, 2016 , p. 327-334, ISSN 1213-2489

[17] DRBÚL, M., STANČEKOVÁ, D., BABÍK, O., HOLUBJAK, J., GÖRÖGOVÁ I., VARGA, D. (2016). Simulation Possibilities of 3D Measuring in Progressive Control of Production. In: Manufacturing Technology, vol. 16, 2016, p. 53-58, ISSN 1213-2489

[18] STANKOVIČOVÁ, Z., DEKÝŠ, V., NOVÁK, P., SAPIETA, M. (2015). Numerical Simulation of Thermoelastic Stress Analysis. In: Manufacturing Technology, vol. 15, 2015, p. 925-930, ISSN 1213-2489

Copyright (C) 2016. Published by Manufacturing Technology. All rights reserved. 